\title{
FROM THE MANAGING EDITOR
}

After six years with RADIOCARBON, I am leaving to take an editorial position at the University Press of Virginia in Charlottesville, my wife's home town (where she has also found a good job in her field). Kimberley Elliott, who has been with RADIOCARBON since the week after I started, will take over as managing editor.

So for the second issue in a row one of our editors is saying farewell to readers, authors, and the radiocarbon community. The latter was a completely new world to me when I began: my previous editorial work and academic training had mostly been in the humanities and social sciences other than archaeology. But Renee Kra was a careful mentor, and the challenge she offered her junior editors to carry on her standards of excellence is one of her many legacies to the journal.

When I joined the staff in 1993, I had just begun to figure out what HTML was all about, and thought it might be fun to see if I could get a World Wide Web page running for RADIOCARBON. (In fact, we had a gopher server before we had a Web server. If you remember gopher servers, consider yourself an Internet old-timer.) I had no idea that within six years the Internet would become not only the university's but the world's dominant vehicle for communication and sales, or that we would be shipping entire issues of the journal to our printing company on a few floppy disks (in PDF format) instead of sending a large box full of camera-ready pages and photographs. But despite the computer revolution, I expect the familiar red-covered paper RADIOCARBON to be our medium for years to come-in fact, we've been gratified by how many orders we've had in recent months for full sets of back issues, which take up several meters of physical space on the shelf.

I leave the journal having come to understand and appreciate what I can only call the poetry of radiocarbon dating. In a famous passage of James Joyce's Ulysses, Stephen Daedalus walks along the seashore, noting evidence of shipwreck in bits of debris and of the moon's pull in the nearing tide, and echoes the German theosophist Jakob Boehme in musing, "Signatures of all things I am here to read." What for Boehme was a mystic exercise in seeing the pattern of the Divine running through the physical world is for the isotope researcher a literal truth. From the isotopic signatures in bones of Viking burials we infer what Eric the Red ate in the 10th century; from those in ice extracted from hundreds of meters below the Greenland ice cap we refine our estimates of climate change in the late Pleistocene. In publishing articles that report and analyze such data, RADIOCARBON adds to the story of where we and our planet have been, and to educated guesses about where we may be headed. (Or where our thermometers and sea levels are headed, at least.)

As anyone will understand who has visited Tucson, it is not easy to leave an office that looks north to the Santa Catalina mountains. I will miss the Sonoran Desert and the radiocarbon community alike, and look forward to occasions for revisiting both when I can.

\section{David Sewell}

